\title{
Mitigating Climate Change by the Development and Deployment of Solar Water Heating Systems
}

\author{
S. T. Wara and S. E. Abe \\ Department of Electrical and Electronics Engineering, College of Engineering, Federal University of Agriculture Abeokuta, \\ Ogun State, Nigeria
}

Correspondence should be addressed to S. T. Wara; warast@funaab.edu.ng

Received 27 January 2013; Revised 12 May 2013; Accepted 18 May 2013

Academic Editor: Ching Yuan Chang

Copyright ( 2013 S. T. Wara and S. E. Abe. This is an open access article distributed under the Creative Commons Attribution License, which permits unrestricted use, distribution, and reproduction in any medium, provided the original work is properly cited.

\begin{abstract}
Solar energy is becoming an alternative for the limited fossil fuel resources. One of the simplest and most direct applications of this energy is the conversion of solar radiation into heat, which can be used in Water Heating Systems. Ogun State in Nigeria was used as a case study. The solar radiation for the state was explored with an annual average of $4.775 \mathrm{kWh} / \mathrm{m}^{2}$ recorded. The designed system comprised storage tanks and the collector unit which comprises wooden casing, copper tube, and aluminium foil. Test results for the unlagged and lagged storage tanks for water temperature at various angles of inclination $\left(2.500^{\circ}-20.000^{\circ}\right)$ were on the average $27.800^{\circ} \mathrm{C}$ and $28.300^{\circ} \mathrm{C}$, respectively, for the inlet temperature and $60.100^{\circ} \mathrm{C}$ and $63.000^{\circ} \mathrm{C}$ for the outlet temperature, respectively. The efficiency of the Solar Water Heating System was $72.500 \%$ and the power saved $2.798 \mathrm{~kW}$. The cost of the unit is put at 1121,400 (\$145) as at August 2012. The unit developed can be applied for the purpose of reducing the cost of energy, dealing with environmental challenges, and improving the use of energy, hence serving as a climate mitigation process as this can be extended for water heating for domestic and other industrial purposes.
\end{abstract}

\section{Introduction}

Solar energy happens to be a naturally occurring renewable source of energy that is gotten directly from one of the major heavenly bodies known as the sun. It has been in existence since the creation of the world and of mankind, but its potentials have not been and could not be harnessed as a result of ignorance and lack of the right technology until now as a result of increase in the demand of power energy supply for human consumption, basically for industrial, commercial, and domestic uses.

The total deposit of fossil fuels left on earth is not up to the amount of energy that could be supplied in a couple of days by the sun which happens to be the root of all energy sources. Therefore, there is a need to changeover to renewable energy sources because of the skyrocketing cost of oil and gas in the production of electricity and the effects of pollutants on climate change (including global warming and ozone layer depletion); especially when it comes to the area of domestic and commercial water heating, solar energy can be a very good substitute to the conventional way of water heating. One of the biggest uses of electricity, gas, and oil is the heating of water in home, offices, schools, and hospitals. Solar water heating is a very simple and efficient way to tap energy from the sun and use it. Solar water heaters concentrate diffused solar radiation into thermal energy [1].

Some of the limitations are the following

(1) the sun is not usually out every time of the year; even when it is out at times, it may not be enough to cater for our energy requirements and needs depending on its intensity;

(2) the facilities required to harness this energy resource are very expensive to put in place;

(3) management of these facilities requires special attention and training on the equipment to avoid misuse. 


\section{Literature Review}

Solar water heaters can operate in any climate. The performance of these heaters varies depending on how much solar energy is available at that locality. Jaisankar et al. [2] reported a comprehensive review on solar water heaters. They reported that the efficiency of solar thermal conversion is about $70 \%$ when compared to solar electrical direct conversion system, which has an efficiency of only $17 \%$. Owing to its ease of operation and simple maintenance, Solar Water Heating systems play an important role in domestic as well as industrial sectors.

The first published analysis of thermosyphon solar water heater circuit was by Close [3]. There have been many other publications on the analysis of these systems but they are all based on the original formulation. For verifying the theoretical results, he tested two thermosyphon systems with different characteristics and the results conformed well to those predicted.

In communities throughout the developing world, poor households struggle to meet their hot water needs. Some households rely on biomass to heat water. In many countries demand for fuel wood is one of the principal contributors to deforestation. Others rely on electricity or liquid fuels such as propane to heat their water. These fuel options are unsustainable as they are costly to households and contribute to the build-up of greenhouse gases in the atmosphere. Many communities face limited or intermittent access to fuel and/or electricity, limiting their ability to access hot water for hygiene and domestic uses. One potential solution to this problem is the use of solar energy to heat water. Water enters at the bottom and is "baked" in the sun. As it warms, hot water travels to the top of the tank due to its lower density. When the water is ready for use, cool water is supplied to the inlet and hot water flows out the top. Access to a low cost solar water heater would provide numerous benefits to households in developing communities. Many households could reduce their fuel costs by eliminating or reducing their need for wood, gas, or electricity to heat water. Substituting traditional fuel sources with solar energy would reduce carbon emissions. Further reduction in biomass consumption would relieve stress on depleted forests. There are also health benefits associated with solar hot water due to lessened exposure to toxins and pollutants released from burning fuels. By enabling access to hot water, households could improve their health and hygiene. Nigeria happens to be one of the few countries that have not really adopted the use of solar water heating methods considering the fact that the intensity of the sun in many areas of the country is so much such as the northern parts where the sun is at the highest intensity.

\section{Methodology}

3.1. Solar Insolation: How Much Heat Is Available? The sun is the energy source but we need to know how much of the sun's energy reaches a particular place. Solar insolation is the amount of electromagnetic energy (solar radiation) incident on the surface of the earth [5]. Basically that means how

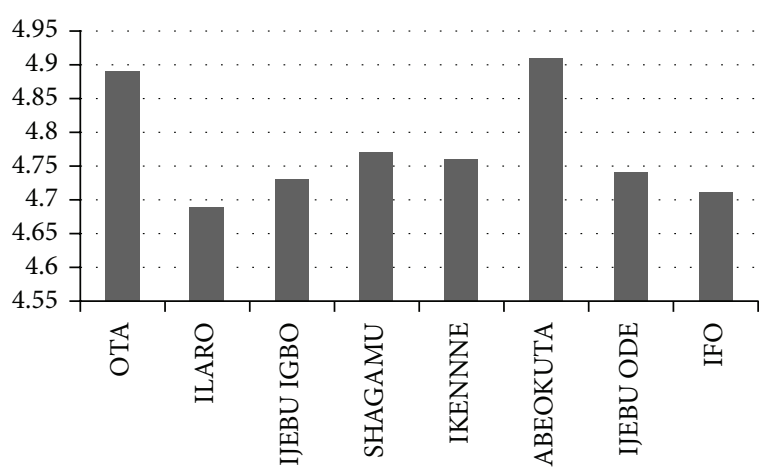

FIGURE 1: Graph showing average monthly solar insolation for Ogun State, Nigeria.

much sunlight is shining down. By knowing the insolation levels of a particular region we can determine the size of solar collector that is required. An area with poor insolation levels will need a larger collector than an area with high insolation levels. Once you know your region's insolation level you can more accurately calculate collector size and energy output. The values are generally expressed in $\mathrm{kWh} / \mathrm{m}^{2}$. This is the amount of solar energy that strikes a square metre of the earth's surface in a single day. This value is averaged to account for differences in the days' length (Figure 1, Table 1). Metrological data from the National Aeronautics and Space Administration (NASA) is used. The NASA website has 22+ years of metrological data stored according to longitude and latitude (Table 5):

$$
\begin{aligned}
& (4.890+4.690+4.730+4.770+4.760+4.910 \\
& \quad+4.740+4.710) \times 8^{-1}=\frac{38.200}{8}=4.775 \mathrm{kWh} / \mathrm{m}^{2} .
\end{aligned}
$$

3.1.1. Conduction: Heat Transfer. In the construction of the Solar Heating System, thermal conductivity is a high priority consideration. The materials with the highest thermal conductivity are metals. The heat received via radiation must be conveyed to the water via conduction (Table 2).

3.1.2. Collector Heat Loss Coefficient $\left(U_{L}\right)$. Heat loss is not to be taken lightly, because it determines how hot the water can become. $U_{L}$, the loss factor, is mainly determined by the number of covers and the wind speed. It also increases a little at high absorber temperatures. For one cover $U_{L}=$ $5.5 \mathrm{~W} / \mathrm{m}^{2} \mathrm{~K}$ and for two covers $U_{L}=3.0 \mathrm{~W} / \mathrm{m}^{2} \mathrm{~K}$ [5]. The solar collector in the Solar Water Heating System uses one cover due to the availability and cost considerations of the cover material.

3.1.3. Transmission Coefficient of Glazing. Radiation passing through the glazing material is said to be transmitted. Transmittance not only varies for different materials but also varies with the wavelength of the radiation. It is therefore desirable to know the spectral transmittance of glazing for 
TABLE 1: Monthly solar insolation for major towns in Ogun State [1].

\begin{tabular}{lcccccrrr}
\hline & \multicolumn{7}{c}{ Monthly averaged insolation incident on a horizontal surface $\left(\mathrm{kWh} / \mathrm{m}^{2}\right)$} & \\
& OTA & ILARO & IJEBU IGBO & SHAGAMU & IKENNNE & ABEOKUTA & IJEBU ODE & IFO \\
\hline January & 5.570 & 5.200 & 5.320 & 5.300 & 5.320 & 5.500 & 5.280 & 5.240 \\
February & 5.740 & 5.410 & 5.480 & 5.480 & 5.500 & 5.700 & 5.490 & 5.450 \\
March & 5.660 & 5.410 & 5.370 & 5.480 & 5.460 & 5.640 & 5.460 & 5.430 \\
April & 5.340 & 5.180 & 5.210 & 5.250 & 5.230 & 5.350 & 5.210 & 5.200 \\
May & 5.010 & 4.710 & 4.790 & 4.790 & 4.770 & 5.090 & 4.760 & 4.720 \\
June & 4.510 & 4.000 & 4.150 & 4.070 & 4.050 & 4.570 & 4.040 \\
July & 3.890 & 3.910 & 3.880 & 3.990 & 3.980 & 4.000 & 4.000 \\
August & 3.730 & 3.920 & 4.040 & 3.990 & 3.980 & 3.790 & 3.950 \\
September & 4.050 & 4.040 & 3.960 & 4.120 & 4.100 & 4.110 & 3.910 \\
October & 4.620 & 4.520 & 4.440 & 4.590 & 4.560 & 4.700 & 4.090 & 4.550 \\
November & 5.180 & 4.900 & 4.950 & 4.980 & 4.960 & 5.110 & 4.060 \\
December & 5.370 & 5.120 & 5.210 & 5.200 & 5.190 & 5.350 & 4.950 \\
Annual average & 4.890 & 4.690 & 4.730 & 4.770 & 4.760 & 4.910 & 4.920 \\
\hline
\end{tabular}

Average insolation for all the towns is $4.775 \mathrm{kWh} / \mathrm{m}^{2}$.

TABLE 2: Thermal conductivity of some metals at $68^{\circ} \mathrm{F}\left(20^{\circ} \mathrm{C}\right)$ [4].

\begin{tabular}{lc}
\hline Material & Thermal conductivity $\left(\mathrm{Btu} /\left(\mathrm{hr}^{\circ} \mathrm{Fft}\right)\right)$ \\
\hline Pure copper & 223 \\
Pure aluminium & 118 \\
Stainless steel & $7-26$ \\
Pure iron & 42 \\
Pure silver & 235 \\
\hline
\end{tabular}

TABLE 3: Transmission coefficients of sample materials [5].

\begin{tabular}{lc}
\hline Material & Transmission coefficient \\
\hline Single 4 mm glass or acrylic sheet & 0.850 \\
Double 4 mm glass & 0.720 \\
Teflon thin film & 0.950 \\
Tedlar thin film & 0.900 \\
\hline
\end{tabular}

Transmission coefficients of sample materials;all of thesecan be reduced by 1 or $2 \%$ due to dirt, up to $8 \%$ in dry dusty areas.

Solar Water Heating Systems. Ideally, the glazing should be very transparent to incoming shortwave radiation but opaque to outgoing long wave (thermal) radiation, because radiant losses may account for over 70 per cent of collector heat loss (Table 3).

3.1.4. Absorptance and Emissivity. Radiation striking an object is absorbed if the energy is retained by the material. For example, a black hose left in the sun heats up as it absorbs energy from the sun. The percentage of incoming radiation that is absorbed by a material is referred to as its absorptance and is a measure of the ease with which a material or surface collects energy. Table 4 presents absorptance for various materials in sunlight. The best materials are those with high absorptance and very low emittance.

The high absorptance and low cost of black paint make it a good choice for the Solar Water Heating System.
TABLE 4: Absorptance and emissivity of sample materials [4].

\begin{tabular}{lcc}
\hline Material & Absorptance & Emissivity \\
\hline Black paint & 0.950 & 0.875 \\
White paint & 0.200 & 0.900 \\
Polished aluminium & 0.100 & 0.050 \\
Selective surfaces & $0.850-0.950$ & $0.120-0.080$ \\
\hline
\end{tabular}

3.2. Efficiency of Collector. In the design of the "Automated Solar Water Heater System" the collector area is another important design consideration. Using the efficiency equation of the flat plate collector, this is given as the heat gained by water with respect to the actual solar energy received by the flat plate collector

$$
m c_{p} \Delta T=A_{c} I \eta
$$

(see [8]) where $m=$ mass of water in kilograms $(\mathrm{kg}), c_{p}=$ specific heat of water $\left(\mathrm{J} / \mathrm{g}^{\circ} \mathrm{C}\right), \Delta T=$ temperature difference (outlet temperature-inlet temperature ${ }^{\circ} \mathrm{C}$ ), $A_{\mathrm{c}}=$ area of collector, $I=$ intensity of solar radiation, $\left(\mathrm{W} / \mathrm{m}^{2}\right)$, and $\eta=$ collector efficiency.

The equation simply equates the heat acquired by the collector to the heat received by the water. If the collector Area $\left(A_{c}\right)$ is made the subject of the formula, (2) becomes

$$
A_{c}=\frac{m c_{p} \Delta T}{\eta I}
$$

(see [8]). The equation above requires us to know the mass of water to be heated, the specific heat of water $\left(c_{p}\right)$ which is a constant $\left(4.18 \mathrm{~J} / \mathrm{g}^{\circ} \mathrm{C}\right)$, the outlet and inlet water temperature, the solar insolation of the environment, and the efficiency of the collector. All parameters are known except the efficiency of the collector which is a value set by the materials used for construction and some constants. The efficiency of the collector therefore must be calculated. 
Equation (4) shows the instantaneous thermal efficiency $(\eta)$ equation for flat plate collectors:

$$
\eta=F_{R} \tau \alpha-F_{R} U_{L}\left(\frac{T_{i}-T_{a}}{I}\right)
$$

(see [8]), where $F_{R}=$ collector heat removal factor, $I=$ intensity of solar radiation, $\mathrm{W} / \mathrm{m}^{2}, T_{i}=$ inlet fluid temperature, ${ }^{\circ} \mathrm{C}, T_{a}=$ ambient temperature, ${ }^{\circ} \mathrm{C}, U_{L}=$ collector heat loss coefficient, $\mathrm{W} / \mathrm{m}^{2} \mathrm{~K}, \tau=$ transmission coefficient of glazing, and $\alpha=$ absorption coefficient of plate.

The equation shows that the efficiency of a flat plate collector is dependent on the transmission coefficient of glazing $(\tau)$, the absorption coefficient of plate, collector heat removal factor $\left(F_{R}\right)$, intensity of solar radiation $(I)$, ambient temperature $\left(T_{a}\right)$, inlet fluid temperature $\left(T_{i}\right)$, and the collector overall heat loss coefficient $\left(U_{\mathrm{L}}\right)$.

For the Solar Water Heating System from the efficiency equation, $F_{R}, \tau, \alpha$, and $U_{L}$ are fixed by the collector design. $T_{i}, T_{a}$, and $I$ are variables determined by the application. This simply implies that the solar collector efficiency can change when $T_{i}, T_{a}$, and $I$ are changed. Using Ogun State as a case study the following where decided in design.

Transmission coefficient of glazing $(\tau)$ will be 0.850 because a single $4 \mathrm{~mm}$ sheet of glass was used in glazing. The absorption coefficient of plate was 0.950 because the collector plate was be painted black. The collector heat removal factor $\left(F_{R}\right)$ was 0.900 ; intensity of solar radiation $(I)$ was $4.775 \mathrm{kWh} / \mathrm{m}^{2}$ from metrological data from NASA. The ambient temperature $\left(T_{a}\right)$ was $25.700^{\circ} \mathrm{C}$ from metrological data from NASA and inlet fluid temperature $\left(T_{i}\right)$ can vary at any point but it was assumed to be $22^{\circ} \mathrm{C}$ in the mornings and the collector overall heat loss coefficient $\left(U_{L}\right)$ was $5.500 \mathrm{~W} / \mathrm{m}^{2} \mathrm{~K}$ because only one layer of glazing was used.

Using (4), if the whole temperature is converted to kelvin the efficiency $\eta$ will be $73.100 \%$.

3.3. Collector Tubing. Copper tubes vary from $1 / 2$ to 1 inch. The $1 / 2$ inch copper tube was used because of more heating per surface area. The small size of the $1 / 2$ inch copper tube allows for more copper tube per surface area of collector.

3.4. Collector Casing. The purpose of the casing is to provide the collector with some insulation, so as to better prevent heat loss into the environment and also to make the collector more presentable. The collector casing was made of wood since wood is better insulator than any metal.

3.5. Collector Placement: Angle of Inclination. The direct sun power incident on a solar collector depends not only on the power contained in the sunlight, but also on the angle between the solar collector and the sun. When the absorbing surface and the sunlight are perpendicular to each other, the power density on the surface is equal to that of the sunlight (in other words, the power density will always be at its maximum when the solar panel is perpendicular to the sun).

For a collector to function optimally, it should be inclined at a specific angle [9], and large deviations from the optimum angle will result in important losses in energy produced.
In tropical regions, where latitude is less than 36 degrees, the duration of effective collector irradiation is constant the whole year [9].

3.6. Power Saved. Through the use of the automated solar water heater, dependency on electric power can be reduced which would lead to savings on power. The power input of the solar water heater can be calculated as

$$
\mathrm{Pi}=I \tau \alpha
$$

(see [5]), where $P i=$ power input, $\tau=$ cover transmissivity, $\alpha=$ surface black absorptance, and the power output was calculated using $\mathrm{Po}=\mathrm{Pi} \cdot \eta$.

3.7. Carbon Footprint Calculation. Carbon (IV) oxide $\left(\mathrm{CO}_{2}\right)$ emission $=$ fuel consumption $\times$ fuel emission factor (Tonnes $\mathrm{CO}_{2}$-emission $=$ litre $\times \mathrm{kg} \mathrm{CO}$ per litre fuel/1000) (Table 6).

Assuming a generator operating for 30 days in a month, consuming 4 litres of fuel per day for water heating.

For gasoline: Tonnes $\mathrm{CO}_{2}$-emission $=(4$ litres $\times 30$ days) $\times 0.0024=0.288$ tons of $\mathrm{CO}_{2}$.

For diesel: Tonnes $\mathrm{CO}_{2}$-emission $=(4$ litres $\times 30$ days $)$ $\times 0.0027=0.324$ tons of $\mathrm{Co}_{2}$.

3.8. Summary of Design Parameters. These are as presented in Table 7.

\section{Construction Methods}

Figure 2 shows the heat collector system whilst Figure 3 shows the entire Solar Water Heating System including the storage tank. The copper tube was bent to form a coil shape with the fins attached to it. It was painted black in order to absorb more heat from the sun, basically converting solar energy to heat energy. This copper tube need to be placed in a case. A wooden case was made to hold copper tube. The wooden case was also painted black. Aluminium foil was placed at the back of the wooden case. The reason for this is that the backing should not warm up but only the collector is to absorb heat. The foil will take any sun that was not absorbed by the collector on the first pass and bounce it back over the collector for another try at absorption. The glass is then placed on top of the wooden case. The glass cover will keep all the heat inside the panel for further absorption. This serves to trap the whole infrared radiation from the sun inside our panel where our collector will absorb it. Light can pass through glass, but heat cannot.

\subsection{Advantages of the Solar Water Heating System}

(i) Full incorporation of solar system as a source of energy for domestic consumption,

(ii) provides a cheaper and more effective way of generating energy for domestic and commercial purposes, 
TABLE 5: Table showing the longitude and latitude of towns in Ogun State $[3,6]$.

\begin{tabular}{lccc}
\hline Towns & Longitude & Latitude & Postal code \\
\hline OTA & $4.780^{\circ}$ & $7.950^{\circ}$ & 112264 \\
ILARO & $3.300^{\circ}$ & $6.530^{\circ}$ & 111101 \\
IKENNE & $3.720^{\circ}$ & $6.870^{\circ}$ & 121103 \\
IJEBU ODE & $3.580^{\circ}$ & $6.470^{\circ}$ & 120252 \\
IJEBU IGBO & $4.100^{\circ}$ & $6.560^{\circ}$ & 120105 \\
IFO & $3.196^{\circ}$ & $6.814^{\circ}$ & 112104 \\
ABEOKUTA & $3.350^{\circ}$ & $7.150^{\circ}$ & 110001 \\
SHAGAMU & $3.650^{\circ}$ & $6.850^{\circ}$ & 121101 \\
\hline
\end{tabular}

TABLE 6: $\mathrm{CO}_{2}$ emission factors for combustion of common fossil fuels [7].

\begin{tabular}{lcccc}
\hline $\begin{array}{l}\text { Fuel } \\
\text { type }\end{array}$ & $\begin{array}{c}\text { Metric tons } \\
\mathrm{CO}_{2} \text { per } \\
\text { litre }\end{array}$ & $\begin{array}{c}\text { Metric tons } \\
\mathrm{CO}_{2} \text { per } \\
\text { gallon }\end{array}$ & $\begin{array}{c}\text { Metric tons } \\
\mathrm{CO}_{2} \text { per } \\
\text { cubic meter }\end{array}$ & $\begin{array}{c}\text { Metric tons } \\
\mathrm{CO}_{2} \text { per } \\
\text { therm }\end{array}$ \\
\hline $\begin{array}{l}\text { Gasoline } \\
\text { Diesel }\end{array}$ & 0.0024 & 0.0092 & - & - \\
Jet fuel & 0.0027 & 0.0104 & - & - \\
$\begin{array}{l}\text { Aviation } \\
\text { gasoline }\end{array}$ & 0.0024 & 0.0090 & - & - \\
LPG & 0.0016 & 0.0060 & - & - \\
CNG & - & - & 0.0022 & - \\
\hline
\end{tabular}

TABle 7: Design specification for the Solar Water Heating System.

\begin{tabular}{lc}
\hline Component & Specification \\
\hline Collector area & \\
Length & 9 meters \\
Collector tube/pipe & Copper \\
Diameter & 0.500 inches \\
& $=0.013$ meters \\
Length & 9 meters \\
Inclination of flat plate collector & $10^{\circ}$ \\
Absorber & Copper painted black \\
Number of glass cover & (emissivity $=0.875)$ \\
Aluminium foil & One (4 mm thick) \\
Length & 0.840 meters \\
Breadth & 0.450 meters \\
\hline
\end{tabular}

(iii) evaluates the performance of the solar water heater prototypes ensuring easy construction, repair, and maintenance,

(iv) provides an alternative for the conventional method of water heating for domestic and commercial use,

(v) provides average individuals with ease and accessibility to an alternative source of energy which is affordable, clean and much less dangerous,

(vi) fully optimizes the solar renewable energy source available for domestic and commercial water heating,

(vii) pollution free.
TABLE 8: Inlet temperature and outlet temperature of water in the SWHS.

\begin{tabular}{lccc}
\hline & Date & $\begin{array}{c}\text { Inlet } \\
\text { temperature }\left({ }^{\circ} \mathrm{C}\right)\end{array}$ & $\begin{array}{c}\text { Outlet } \\
\text { temperature }\left({ }^{\circ} \mathrm{C}\right)\end{array}$ \\
\hline Day 1 & $09 / 07 / 2012$ & 28.200 & 58.300 \\
Day 2 & $10 / 07 / 2012$ & 28.000 & 60.000 \\
Day 3 & $11 / 07 / 2012$ & 27.800 & 59.300 \\
Day 4 & $12 / 07 / 2012$ & 28.000 & 60.700 \\
Day 5 & $13 / 07 / 2012$ & 27.500 & 59.700 \\
Day 6 & $14 / 07 / 2012$ & 26.500 & 60.000 \\
Day 7 & $15 / 07 / 2012$ & 27.000 & 60.700 \\
Day 8 & $17 / 07 / 2012$ & 28.000 & 60.700 \\
Day 9 & $18 / 07 / 2012$ & 28.500 & 59.300 \\
Day 10 & $19 / 07 / 2012$ & 28.500 & 62.300 \\
\hline Average & & 27.800 & 60.100 \\
\hline
\end{tabular}

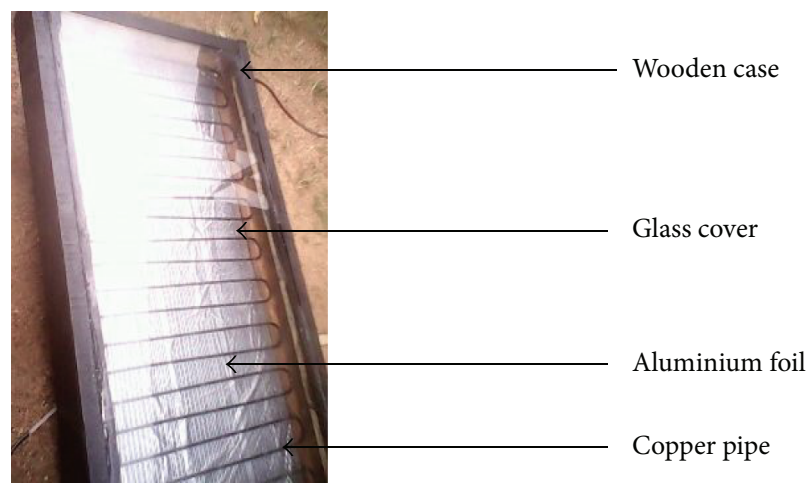

FIGURE 2: Solar water heating (heat collector) system.

4.2. Performance Evaluation/Test and Results. The performance of the Solar Water Heating System was evaluated to determine its reliability in terms of

(i) efficiency,

(ii) power saved.

Testing was carried out on a daily basis between $12 \mathrm{pm}$ and $5 \mathrm{pm}$ for ten days in Camp, Abeokuta, Ogun State. The inlet fluid temperature and outlet fluid temperature was measured using a thermometer. Table 8 shows the average values of the inlet temperature and the outlet temperature per day and the average for the whole test period.

Testing was also carried out for different angles of the solar collector to the horizontal surface. The inlet fluid temperature and outlet fluid temperature ware measured using a thermometer.

Table 9 shows the average values of the inlet temperature and the outlet temperature per day (for different angles) and the average for the whole testing period. A graphical representation of the water heating ability of the developed unit is shown in Figures 4 and 5. 
TABLE 9: Inlet and outlet temperature of water in the SWHS at different angles.

\begin{tabular}{|c|c|c|c|c|c|c|}
\hline Angle $\left(^{\circ}\right)$ & Temperature $\left({ }^{\circ} \mathrm{C}\right)$ & $\begin{array}{c}\text { Day 1 } \\
15 / 08 / 2012 \\
\end{array}$ & $\begin{array}{c}\text { Day 2 } \\
16 / 08 / 2012\end{array}$ & $\begin{array}{c}\text { Day 3 } \\
17 / 08 / 2012 \\
\end{array}$ & $\begin{array}{c}\text { Day } 4 \\
21 / 08 / 2012 \\
\end{array}$ & Average \\
\hline \multirow{2}{*}{2.5} & Inlet temperature & 28.500 & 28.300 & 28.000 & 28.300 & 28.300 \\
\hline & Outlet temperature & 58.200 & 58.300 & 58.000 & 58.700 & 58.300 \\
\hline \multirow{2}{*}{5.0} & Inlet temperature & 28.500 & 28.300 & 28.000 & 28.300 & 28.300 \\
\hline & Outlet temperature & 58.800 & 59.300 & 58.300 & 60.800 & 60.000 \\
\hline \multirow{2}{*}{7.5} & Inlet temperature & 28.500 & 28.300 & 28.000 & 28.300 & 28.300 \\
\hline & Outlet temperature & 60.300 & 60.000 & 59.800 & 60.800 & 60.300 \\
\hline \multirow{2}{*}{10.0} & Inlet temperature & 28.500 & 28.300 & 28.000 & 28.300 & 28.300 \\
\hline & Outlet temperature & 60.700 & 60.000 & 60.700 & 62.300 & 61.000 \\
\hline \multirow{2}{*}{12.5} & Inlet temperature & 28.500 & 28.300 & 28.000 & 28.300 & 28.300 \\
\hline & Outlet temperature & 62.700 & 62.300 & 62.300 & 64.800 & 63.000 \\
\hline \multirow{2}{*}{15.0} & Inlet temperature & 28.500 & 28.300 & 28.000 & 28.300 & 28.300 \\
\hline & Outlet temperature & 64.300 & 65.300 & 63.700 & 65.000 & 64.600 \\
\hline \multirow{2}{*}{17.5} & Inlet temperature & 28.500 & 28.300 & 28.000 & 28.300 & 28.300 \\
\hline & Outlet temperature & 60.800 & 60.700 & 60.300 & 60.200 & 60.500 \\
\hline \multirow{2}{*}{20.0} & Inlet temperature & 28.500 & 28.300 & 28.000 & 28.300 & 28.300 \\
\hline & Outlet temperature & 58.300 & 59.800 & 57.800 & 60.500 & 59.100 \\
\hline
\end{tabular}

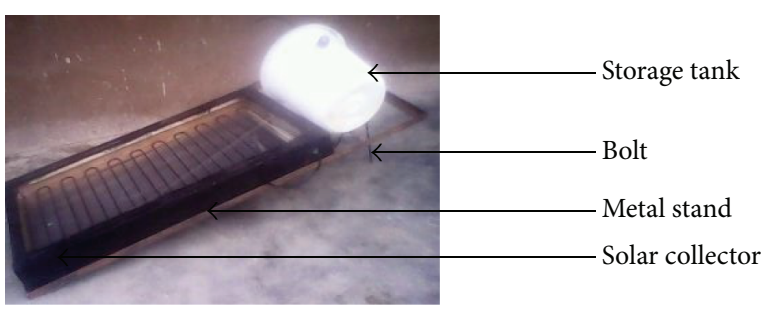

FIGURE 3: The solar water heating system with the stand.

Efficiency of the Solar Water Heating System

$$
\begin{gathered}
\eta=F_{R} \tau \alpha-F_{R} U_{L}\left(\frac{T_{i}-T_{a}}{I}\right), \\
\eta=(0.900 \times 0.850 \times 0.950)-0.900 \times 5.500 \\
\times \frac{(300.800-298.700)}{4775}, \\
\eta=0.72675-0.00217696, \\
\eta=0.725=72.5 \% .
\end{gathered}
$$

Power saved by the Solar Water Heating System

$$
\begin{aligned}
& \mathrm{P}_{i}=4775 \times 0.85 \times 0.95=3.86 \mathrm{~kW}, \\
& \mathrm{P}_{o}=\mathrm{P}_{i .} \eta, \\
& \mathrm{P}_{o}=3.86 \mathrm{~kW} \times 0.725=2.799 \mathrm{~kW} .
\end{aligned}
$$

For a 6-hour period of effective sunlight in a day, the total power output of the solar water heater in a day can be calculated as

$$
2.799 \mathrm{~kW} \times 6 \text { hours }=16.794 \mathrm{kWh} .
$$

TABLE 10: Daily consumption of hot water in a Nigerian home.

\begin{tabular}{lcccc}
\hline Size of family & $\begin{array}{c}\text { Morning } \\
\text { (litres) }\end{array}$ & $\begin{array}{c}\text { Afternoon } \\
\text { (litres) }\end{array}$ & $\begin{array}{c}\text { Evening } \\
\text { (litres) }\end{array}$ & $\begin{array}{c}\text { Total } \\
\text { (litres) }\end{array}$ \\
\hline A family of 5 & 52 & 6 & 5 & 63 \\
A family of 2 & 18 & 3 & 2 & 23 \\
A family of 2 & 20 & 3 & 2 & 25 \\
A family of 4 & 48 & 5 & 4 & 57 \\
\hline
\end{tabular}

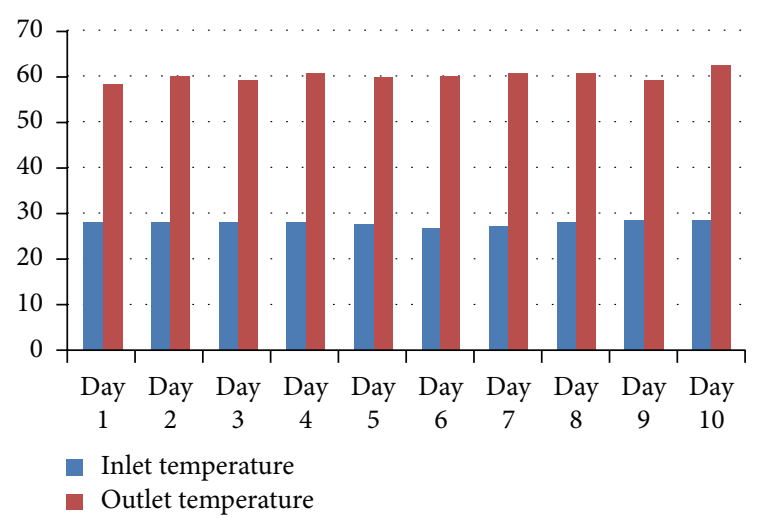

FIGURE 4: Inlet and outlet temprature of water.

Table 10 shows the amount of hot water used up in different Nigerian homes.

From Table 10, average consumption of hot water can be calculated as.

$$
\frac{63+23+25+57}{4}=42 \text { litres. }
$$




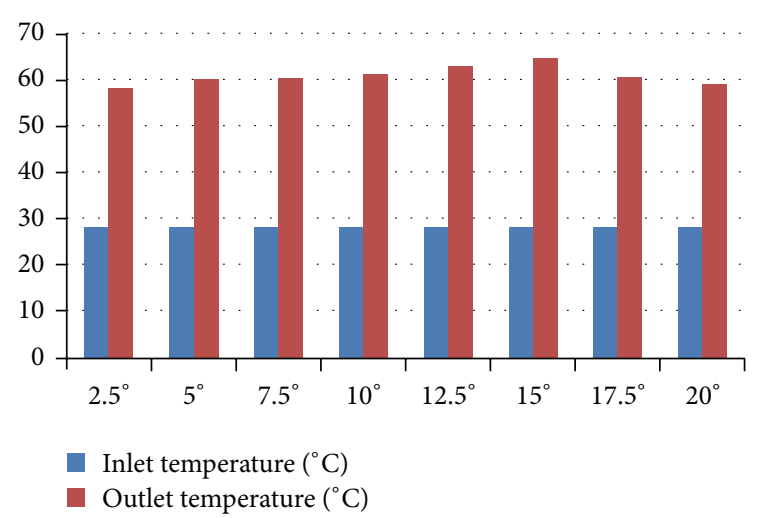

FIGURE 5: Inlet and outlet temperature for the average values at different angles.

TABLE 11: Operation of a $1.5 \mathrm{KW}$ electric heater heating water to $85^{\circ} \mathrm{C}$.

\begin{tabular}{lcc}
\hline Volume (litre) & Duration (hour) & Power (KWh) \\
\hline 0 & 0 & $0 \times 0=0$ \\
1 & 0.057 & $0.057 \times 1.5=0.086$ \\
10 & 0.550 & $0.550 \times 1.5=0.825$ \\
20 & 1.020 & $1.020 \times 1.5=1.530$ \\
30 & 1.490 & $1.490 \times 1.5=2.235$ \\
40 & 1.960 & $1.960 \times 1.5=2.940$ \\
50 & 2.420 & $2.420 \times 1.5=3.630$ \\
60 & 2.880 & $2.880 \times 1.5=4.320$ \\
70 & 3.340 & $3.340 \times 1.5=5.010$ \\
\hline
\end{tabular}

From Table 10, the family of 5 shown consumes about 63 litres of hot water in a day. This is close to 60 litres of hot water. From Table 11, the $1.5 \mathrm{~kW}$ water heater consumes energy of $4.320 \mathrm{kWh}$ in heating 60 litres of hot water. If the family used the solar hot water heater in place of the electric water heater, the amount saved on electric bills daily would be ( $\mathrm{N} 12.90$ is the cost per kWh in Nigeria)

$$
4.32 \mathrm{kWh} \times 12.90 \mathrm{k}=\cong 55.728 \mathrm{k} .
$$

The amount saved in a month would be

$$
\text { } 55.728 \mathrm{k} \times 30=1671.840 \mathrm{k} .
$$

The annual savings on electricity bills would be

$$
\text { 1671.840k } \times 12=\$ 20062.080 \mathrm{k} .
$$

Within a year, the amount saved has summed up to the capital used in purchasing the solar water heater. The work was undertaken and concluded in the month of August 2012. The cost of material used in all aspects of work amounted to $\mathrm{N} 21,400$ as at august 2012 pricing.

\section{Conclusions}

A Solar Water Heating System has been developed using locally available materials and was tested. The solar collector was rotated at different angles, and measurements indicate that the water in the tank was heated by the solar energy being absorbed by the solar collector. The developed unit can be deployed for use in the domestic and commercial sectors. The Solar Water Heating System is environmentally friendly and can readily be used as an alternative water heating saving cost, and reducing the amount of power consumed and carbon emission. Consideration can be given to retrofitting the currently used conventional water heaters.

\section{References}

[1] NASA, "Nasa Surface meteorology and Solar Energy Data Set," 2012, http://eosweb.larc.nasa.gov/cgi-bin/sse/grid.cgi?uid=3030.

[2] S. Jaisankar, J. Ananth, S. Thulasi, S. T. Jayasuthakar, and K. N. Sheeba, "A comprehensive review on solar water heaters," Renewable and Sustainable Energy Reviews, vol. 15, no. 6, pp. 3045-3050, 2011.

[3] D. J. Close, "The performance of solar water heaters with natural circulation," Solar Energy, vol. 6, no. 1, pp. 33-40, 1962.

[4] K. S. Ong, "A finite-difference method to evaluate the thermal performance of a solar water heater," Solar Energy, vol. 16, no. 3-4, pp. 137-147, 1974.

[5] K. Brown, Introduction to Solar Water Heating, Centre for Alternative Technology, London, UK, 2005.

[6] J. A. Duffie and W. A. Beckman, Solar Engineering of Thermal Processes, John Wiley and Sons, New York, NY, USA, 2nd edition, 1991.

[7] GHG, "(Green House Gas Protocol) Calculation Tools for Stationary Emission," 2013, http://www.theice.com/publicdocs/ ccx/CCX_GHG_Factors.pdf.

[8] B. M. Santos, M. R. Queiroz, and T. P. F. Borges, "A solar collector design procedure for crop drying," Brazilian Journal of Chemical Engineering, vol. 22, no. 2, pp. 277-284, 2005.

[9] A. Adell, "Determination of the optimum inclination of a flat solar collector in function of latitude and local climatic data," Revue de Physique Appliquée, vol. 17, Article ID 576, p. 569, 1982. 


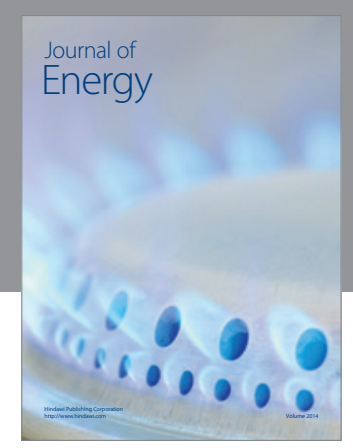

Journal of

Industrial Engineering
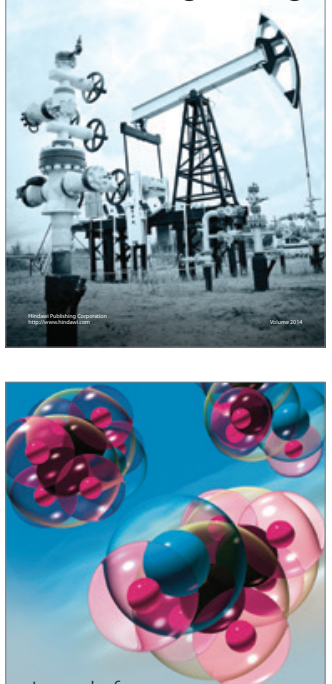

Fuels
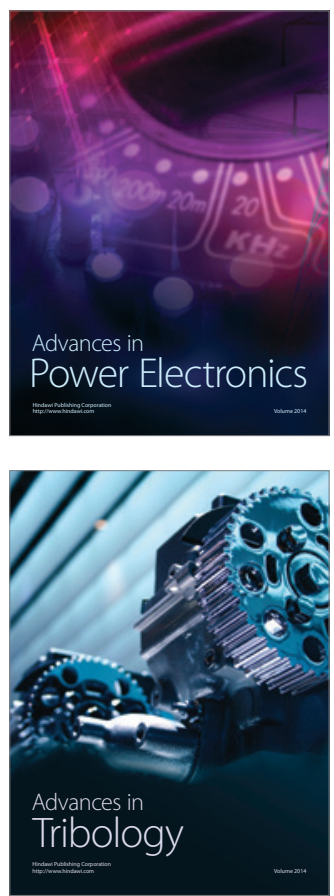

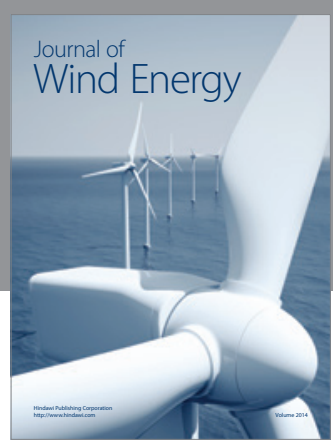

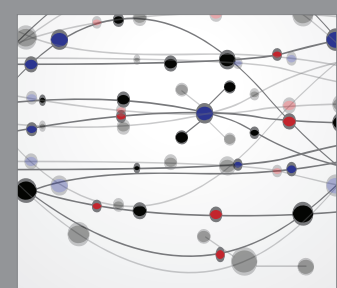

The Scientific World Journal

Submit your manuscripts at http://www.hindawi.com

Journal of

Structures
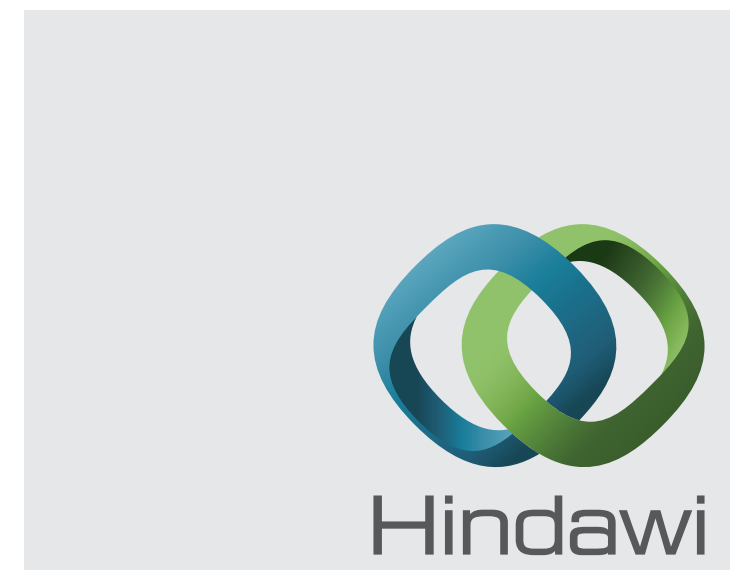

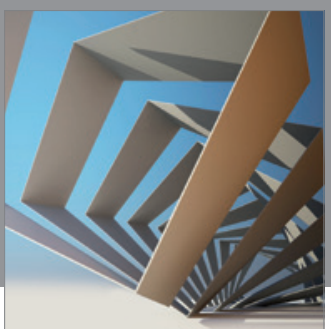

Rotating

Machinery
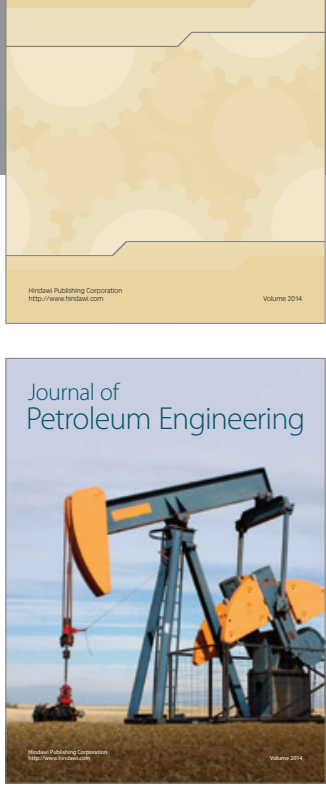

Journal of

Solar Energy
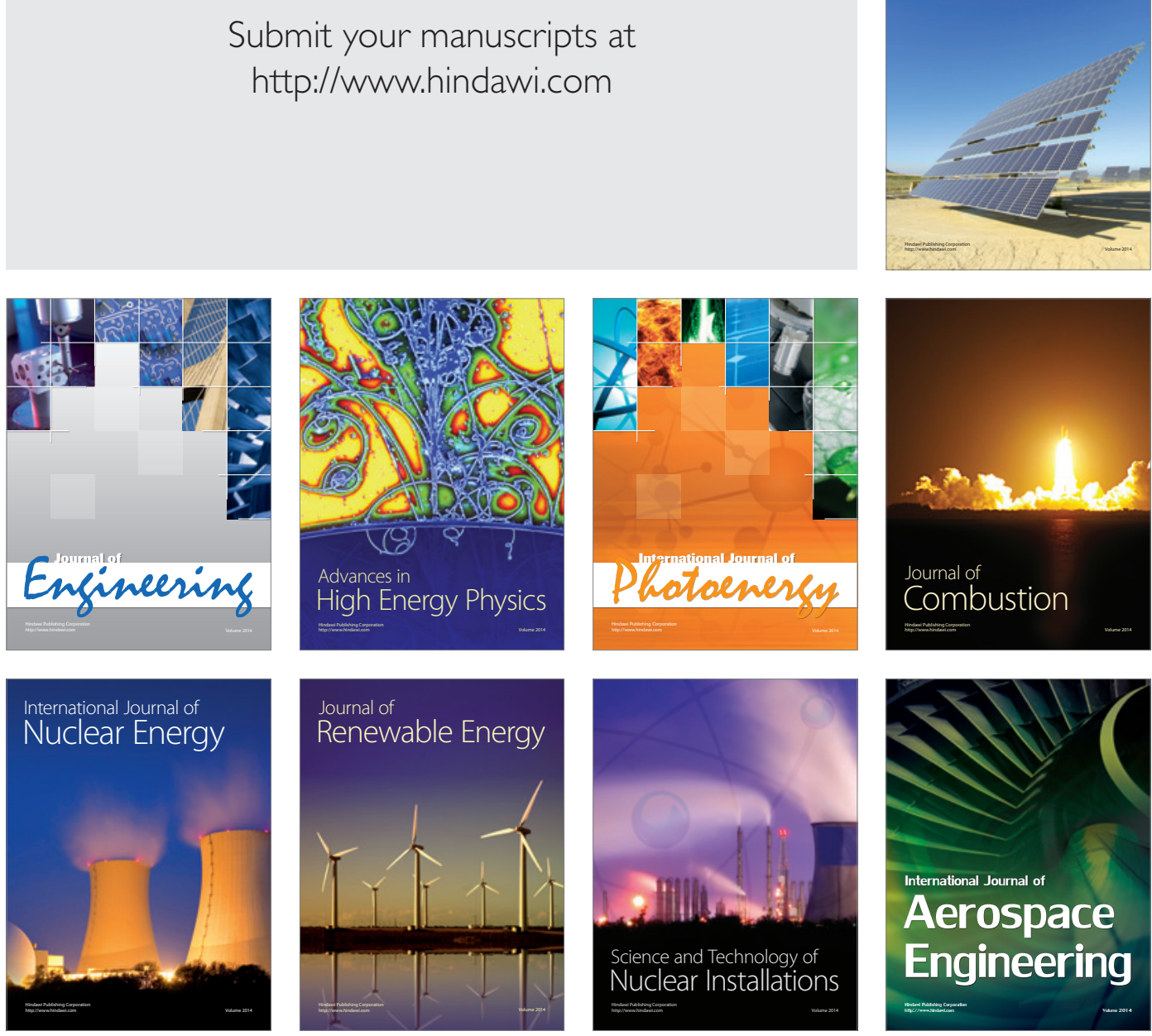